\title{
РЕТРОСПЕКТИВНЫЙ АНАЛИЗ ФОРМ ГОСУДАРСТВЕННОЙ ФИНАНСОВОЙ ПОДДЕРЖКИ ИНВЕСТИЦИОННЫХ ПРОЕКТОВ В ПРОМЫШЛЕННОСТИ РЕСПУБЛИКИ БЕЛАРУСЬ
}

\begin{abstract}
А.С. Голикова, А.А. Матяс
Представлен ретроспективный анализ форм и критериев государственной финансовой поддержки реализации инвестиционных проектов в промышленности Республики Беларусь на основе использования соответствующих нормативно-правовых актов, фактических данных органов госуправления, банковского сектора и отдельных модернизированных коммерческих организаций, а также выявлены особенности, отдельные тенденции, существующие проблемы, возможные направления и меры по ее постепенной трансформации и рационализации.
\end{abstract}

Ключевые слова: Республика Беларусь, формы государственной финансовой поддержки, инвестиционные проекты, промышленность.

JEL-классификация: H54, H81.

DOI: $10.46782 / 1818-4510-2021-4-89-112$

Материал поступил 6.12.2021 2.

В условиях доминирования государственного сектора в белорусской экономике (особенно в промышленности), а также макроэкономической и монетарной нестабильности на протяжении длительного времени для поддержания инвестиций в Беларуси активно использовались различные формы государственной поддержки при реализации инвестиционных проектов. При этом чрезмерное инвестирование с применением недостаточно эффективных форм и инструментов бюджетного финансирования и льготного целевого кредитования посредством реализации соответствующих госпрограмм, в свою очередь, способствовало усилению дисбалансов и сохранению макроэкономической нестабильности.

В последние годы сократились финансовые возможности госбюджета и банковской системы по господдержке экономики, что связано как с ухудшением внешнеторговой конъюнктуры, ужесточением со стороны Рос- сийской Федерации условий поставки энергоносителей, так и необходимостью обслуживания образовавшегося в предыдущие годы государственного долга. В свою очередь, проседание внешнего и внутреннего спроса, существенная корректировка отдельных макроэкономических индикаторов (прежде всего в части обменного курса белорусского рубля и инфляции), а также затягивание первоначально установленных сроков строительства повлияли на адекватность и обоснованность расчетов инвестиционных проектов, заложенных в бизнес-планы. Как следствие, реализованные за счет масштабных внешних и внутренних заимствований и финансовой поддержки государства инвестиционные проекты не привели к ожидаемым завышенным результатам и генерированию соответствующей валютной выручки, а ранее дефицитные производственные мощности в отдельных отраслях, продукция которых преимущественно коррелирует с инвестициями и стро-

* Голикова Анна Сергеевна (anna.golikova@mail.ru), кандидат экономических наук, доцент, Полесский государственный университет (г. Пинск, Беларусь). https://orcid.org/0000-0003-4798-5786;

Матяс Александр Анатольевич (alexandermatyas@yandex.ru), кандидат экономических наук, доцент, Полесский государственный университет (г. Пинск, Беларусь). https://orcid.org/0000-0002-8546-4570 
ительством, после их сплошной модернизации оказались недозагруженными. Одновременно в целях макроэкономической стабилизации в условиях значительного ухудшения внешнеторговой конъюнктуры на традиционные товарные позиции высококонцентрированного белорусского экспорта в качестве одной из компенсационных мер пришлось использовать сокращение внутреннего инвестиционного спроса. Достаточно отметить, что инвестиции в основной капитал по отношению к предыдущему году сократились в 2014 г. на 5,9\%, 2015 г. - на 18,8\%, 2016 г. - на 17,4\%, или в общей сложности более чем на $40 \%$. Аналогичная ситуация складывается и в последние годы. Так, в 2020 г. данный показатель уменьшился на 6\%, за 10 месяцев текущего года - на 7,8\% ${ }^{1}$.

В сложившихся условиях не остается другого выхода, как последовательно сокращать господдержку и льготное кредитование экономики и инвестиционных проектов, что и происходит в последние годы. В связи с этим в статье поставлена задача проанализировать, обобщить и систематизировать применявшиеся в стране формы и критерии господдержки, а также полученные результаты при реализации отдельных инвестиционных проектов в промышленности Республики Беларусь, что в конечном счете будет способствовать рационализации отдельных подходов в данной области.

При проведении исследования использованы в основном нормативные правовые акты, регламентирующие и инициирующие господдержку инвестиционных проектов, а также данные Министерства финансов по результатам их реализации в промышленности с участием государства.

\section{Основные формы и критерии государственной финансовой поддержки реализации инвестищионных проектов в промышленности}

В Республике Беларусь до 2016 г. основным документом, регламентирующим

${ }^{1}$ Статистический ежегодник Республики Беларусь. 2021. С. 26; Социально-экономическое положение Республики Беларусь в январе-октябре 2021. URL: https:// www.belstat.gov.by/ofitsialnaya-statistika/publications/izdania/ public_bulletin/index_41017/ предоставляемые формы государственной финансовой поддержки субъектам хозяйствования, являлся Указ Президента Республики Беларусь № 182 от 28 марта 2006 г. «О совершенствовании правового регулирования порядка оказания государственной поддержки юридическим лицам и индивидуальным предпринимателям» (далее Указ № 182). С принятием нового Указа № 106 от 23 марта 2016 г. «О государственных программах и оказании государственной финансовой поддержки» (далее - Указ № 106) предоставление финансовой помощи, бюджетного займа, ссуды, возмещение части процентов за пользование банковским кредитом было упразднено. Согласно данному Указу, оказание государственной финансовой помощи осуществляется на конкурсной основе только в рамках государственных программ в виде возмещения части расходов на приобретение технологического оборудования и запасных частей из бюджетов и внебюджетных фондов, а также кредитования открытым акционерным обществом «Банк развития Республики Беларусь». Вместе с тем в исключительных случаях по решению Президента Республики Беларусь организациям могут быть предоставлены бюджетные займы за счет средств республиканского или местных бюджетов ${ }^{2}$.

Однако предоставление государственной финансовой поддержки на реализацию инвестиционных проектов не ограничивается только Указом № 106. В табл. 1 представлены формы государственной поддержки, применяемые в Республике Беларусь, а также предъявляемые к ним требования.

Одним из основных требований являются участие и победа в конкурсном отборе. Конкурсы проводятся при предоставлении государственной финансовой поддержки в виде возмещения части расходов на приобретение технологического оборудования и запасных частей ${ }^{3}$. С 28 июля 2016 г. конкурсы также проводятся при выборе инвестора для заключения инвестицион-

2 Указ Президента Республики Беларусь от 23.03.2016 г. № 106 «О государственных программах и оказании государственной финансовой поддержки» (в ред. Указа Президента Республики Беларусь от 14.11.2019 г. № 412) (далее - Указ № 106).

${ }^{3}$ Там же. 
Соотнесение форм государственной финансовой поддержки реализации инвестиционных проектов с требованиями, предъявляемыми к ним

\begin{tabular}{|c|c|c|c|c|c|}
\hline \multirow[b]{2}{*}{$\begin{array}{c}\text { Форма государственной финансовой поддержки инвестиционных } \\
\text { проектов }\end{array}$} & \multicolumn{5}{|c|}{$\begin{array}{c}\text { Требования, предъявляемые } \\
\text { к инвестиционным проектам, для } \\
\text { предоставления государственной } \\
\text { финансовой поддержки }\end{array}$} \\
\hline & $\begin{array}{l}0 \\
0 \\
0 \\
0 \\
0 \\
0 \\
0 \\
0 \\
0 \\
0 \\
0 \\
0 \\
0 \\
5 \\
0 \\
0 \\
0 \\
0 \\
0 \\
0 \\
0 \\
0 \\
0 \\
0 \\
0 \\
0 \\
0 \\
0 \\
0 \\
0 \\
0 \\
0 \\
0 \\
0 \\
0 \\
0 \\
\nu\end{array}$ & 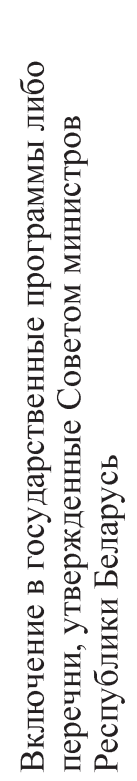 & 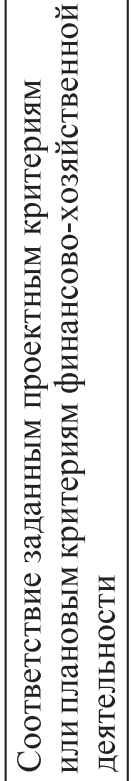 & 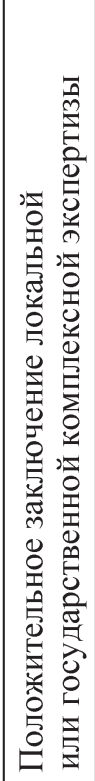 & 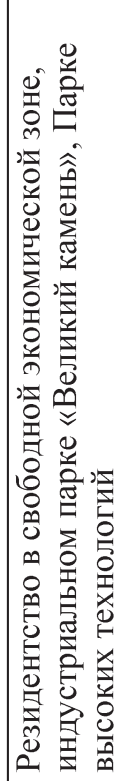 \\
\hline \multicolumn{6}{|l|}{$\begin{array}{l}\text { Освобождение от уплаты налогов, сборов, пошлин, снижение } \\
\text { ставок по ним }\end{array}$} \\
\hline $\begin{array}{l}\text { Предоставление преференций в рамках заключенного } \\
\text { инвестиционного договора }\end{array}$ & 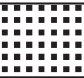 & & & ::::: & \\
\hline Финансовая поддержка из республиканского и местных бюджетов & :i: & & 8.8. & & \\
\hline \multicolumn{6}{|l|}{ Предоставление средств инновационных фондов } \\
\hline $\begin{array}{l}\text { Предоставление кредитов на льготных условиях ОАО «Банк } \\
\text { развития Республики Беларусь» }\end{array}$ & : & & & & \\
\hline \multicolumn{6}{|l|}{$\begin{array}{l}\text { Предоставление средств внебюджетных централизованных } \\
\text { инвестиционных фондов }\end{array}$} \\
\hline Предоставление гарантий Правительства Республики Беларус & & & & & \\
\hline
\end{tabular}

Источник. Авторская разработка на основе: Указ Президента Республики Беларусь от 30.06.2008 г. № 359 «О некоторых вопросах предоставления гарантий Правительства Республики Беларусь по кредитам, выдаваемым банками Республики Беларусь» (в ред. Указа Президента Республики Беларусь от 30.09.2019 г. № 360) (далее - Указ № 359); Декрет Президента Республики Беларусь от 06.08.2009 г. № 10 (в ред. Декрета от 16.07.2019 г. № 4) (далее Декрет № 10); Указ № 168; Указ № 357; постановление № 9; постановление № 347; постановление № 563.

ных договоров ${ }^{4}$. Предусмотрен конкурсный отбор и при финансировании инвестиционных проектов из средств инновационных $\phi_{\text {фондов }}^{5}$, а также при предоставлении кредитов открытым акционерным обществом «Банк развития Республики Беларусь» ${ }^{6}$.

${ }^{4}$ Постановление Совета Министров Республики Беларусь от 19.07.2016 г. № $563 \ll$ мерах по реализации Декрета Президента Республики Беларусь от 6 августа 2009 г. № 10» (в ред. постановления Совета Министров Республики Беларусь от 02.04.2020 г. № 193) (далее - постановление № 563).

5 Указ Президента Республики Беларусь от 07.08.2012 г. № 357 «О порядке формирования и использования средств инновационных фондов» (в ред. Указа Президента Республики Беларусь от 07.05.2020 г. № 156) (далее - Указ № 357).

${ }_{6}^{6}$ Указ № 106.
Часто основным условием для финансового участия государства в реализации инвестиционного проекта является включение коммерческих предприятий в государственные, отраслевые, региональные и иные программы или перечни, утверждаемые Советом Министров Республики Беларусь по согласованию с Президентом ${ }^{7}$.

7 Указ № 106; Указ Президента Республики Беларусь от 21.03.2008 г. № 168 «О некоторых мерах по реализации инвестиционных проектов, финансируемых за счет внешних государственных займов и внешних займов, привлеченных под гарантии Правительства Республики Беларусь» (в ред. Указа Президента Республики Беларусь от 27.06.2011 г. № 275) (далее Указ № 168); постановление Совета Министров Республики Беларусь от 29.04.2016 г. № 347 «Об ут- 
Финансовое участие государства в реализации инвестиционного проекта возможно также и при соответствии проектных данных установленным критериям проектной или финансово-хозяйственной деятельности предприятия. Единой системы критериев не существует, они могут изменять-

верждении положения о порядке проведения конкурса на оказание государственной финансовой поддержки субъектам хозяйствования в виде возмещения за счет средств республиканского и (или) местных бюджетов части расходов на приобретение технологического оборудования и запасных частей» (в ред. постановления Совета Министров Республики Беларусь от 25.05.2018 г. № 396) (далее - постановление № 347); постановление Совета Министров Республики Беларусь от 05.01.2013 г. № 9 «Об утверждении Положения о порядке и целях использования средств внебюджетных централизованных инвестиционных фондов» (в ред. постановления Совета Министров Республики Беларусь от 22.10.2020 г. № 602) (далее - постановление № 9). ся в зависимости от формы государственной финансовой поддержки предприятия. Более того, особенностью поддержки коммерческих предприятий в Республике Беларусь является отсутствие четко заданных критериев, в соответствии с которыми она может быть оказана. Например, условием предоставления финансовой помощи в виде возмещения части расходов на приобретение технологического оборудования и запасных частей является обеспечение повышения прибыльности производимых товаров (работ, услуг) или снижение их себестоимости ${ }^{8}$ В табл. 2 приведены формы государственной финансовой поддержки,

8 Постановление № 347.

Показатели, используемые в качестве критериев при предоставлении различных форм государственной финансовой поддержки

\begin{tabular}{|c|c|c|}
\hline $\begin{array}{c}\text { Форма оказываемой } \\
\text { государственной поддержки }\end{array}$ & $\begin{array}{c}\text { Показатели, используемые в качестве } \\
\text { критериев эффективности }\end{array}$ & $\begin{array}{c}\text { Критерий } \\
\text { эффективности }\end{array}$ \\
\hline $\begin{array}{l}\text { Предоставление денежных } \\
\text { средств из внебюджетных } \\
\text { централизованных } \\
\text { инвестиционных фондов* }\end{array}$ & $\begin{array}{l}\text { Срок окупаемости проекта; } \\
\text { срок валютоокупаемости; } \\
\text { годовая добавленная стоимость } \\
\text { на одного среднесписочного работника; } \\
\text { удельный вес экспортных поставок } \\
\text { в общем объеме реализации }\end{array}$ & $\begin{array}{l}\text { Не установлен нормативно-правовым } \\
\text { актом }\end{array}$ \\
\hline \multirow{2}{*}{$\begin{array}{l}\text { Предоставление денежных } \\
\text { средств из инновационных } \\
\text { фондов }\end{array}$} & $\begin{array}{l}\text { Средний уровень добавленной } \\
\text { стоимости на одного работающего ** }\end{array}$ & $\begin{array}{l}\text { Равенство уровню ЕС или его } \\
\text { превышение }\end{array}$ \\
\hline & Соотношение экспорта и импорта & Превышение экспорта над импортом \\
\hline \multirow{6}{*}{$\begin{array}{l}\text { Предоставление кредитов на } \\
\text { льготных условиях ОАО «Банк } \\
\text { развития Республики Беларусь» }\end{array}$} & Срок окупаемости проекта & $\begin{array}{l}\text { Превышение срока службы основных } \\
\text { средств, вводимых по проекту }\end{array}$ \\
\hline & Внутренняя норма доходности & $\begin{array}{l}\text { Превышение ставки дисконтирования } \\
\text { по проекту или процентной ставки } \\
\text { по долгосрочному кредиту }\end{array}$ \\
\hline & $\begin{array}{l}\text { Добавленная стоимость на одного } \\
\text { работающего по проекту }\end{array}$ & $\begin{array}{l}\text { Превышение установленных } \\
\text { законодательством пороговых значений, } \\
\text { но не менее 16,6 тыс. долл. США }\end{array}$ \\
\hline & Финансовая реализуемость & $\begin{array}{l}\text { Достаточность собственных источников, } \\
\text { заемных и привлеченных средств для } \\
\text { финансирования проекта в планируемые } \\
\text { сроки, положительный накопительный } \\
\text { остаток денежных средств за каждый год } \\
\text { реализации проекта }\end{array}$ \\
\hline & $\begin{array}{l}\text { Коэффициент покрытия } \\
\text { задолженности }\end{array}$ & $\begin{array}{l}\text { Превышение } 1,0 \text { по каждому году } \\
\text { реализации проекта }\end{array}$ \\
\hline & Валютоокупаемость & $\begin{array}{l}\text { Положительные значения сальдо потока } \\
\text { денежных средств в свободной } \\
\text { конвертируемой валюте от текущей } \\
\text { и инвестиционной деятельности } \\
\text { по проекту }\end{array}$ \\
\hline
\end{tabular}

* Могут устанавливаться дополнительные критерии и их нормативные значения.

** Пороговые значения устанавливаются исходя из вида экономической деятельности.

*** Если долгосрочный кредит занимает $60 \%$ и более в структуре источников финансирования инвестиционного проекта.

Источник. Указ № 357; постановление № 9; Требования к бизнес-плану проекта. URL: https://brrb.by/ activity/investment-projects-financing/requirements-to-the-business-plan/?sphrase_id=94458 
при предоставлении которых от предприятия требуется соблюдение определенных показателей, выступающих в качестве критерия эффективности проекта. Наиболее распространенным показателем является уровень добавленной стоимости на одного среднесписочного работника, а критерием превышение им порогового значения, которое устанавливается Советом Министров Республики Беларусь.

Как видим, основными показателями при принятии решения о предоставлении государственной финансовой поддержки являются показатели экономической (добавленная стоимость на одного работающего), финансовой (срок окупаемости, внутренняя норма доходности), валютной эффективности (срок валютоокупаемости, удельный вес экспортных поставок).

Показатели и критерии эффективности также устанавливаются при предоставлении индивидуальных форм государственной финансовой поддержки отдельным коммерческим предприятиям. В частности, нами на основании анализа нормативноправовых документов были выделены следующие показатели, по которым могут задаваться критерии:

- выручка от реализации продукции, товаров (работ, услуг) в расчете на одного среднесписочного работника ${ }^{10}$; труда ${ }^{11}$

- темпы роста производительности

- темпы роста объемов производства ${ }^{12}$;

10 Постановление Совета Министров Республики Беларусь от 04.03.2015 г. № 157 «О мерах по реализации организациями деревообрабатывающей и целлюлозно-бумажной промышленности инвестиционных проектов в 2015 году» (в ред. постановления Совета Министров Республики Беларусь от 24.09.2015 г. № 800) (далее - постановление № 157); Указ Президента Республики Беларусь от 07.05.2014 г. № 216 «О создании производства по выпуску бумаги-основы для декоративных облицовочных материалов» (в ред. Указа Президента Республики Беларусь от 31.12.2019 г. № 507) (далее - Указ № 216).

11 Указ № 216.

12 Указ Президента Республики Беларусь от 01.10.2012 г. № 449 « некоторых вопросах организации производства мелованных и немелованных видов картона» (в ред. Указа Президента Республики Беларусь от 10.02.2020 г. № 44) (далее - Указ № 449); Указ Президента Республики Беларусь от 19.12.2008 г. № 691 «О некоторых вопросах реализации инвестиционных проектов развития цементной промышленности» (в ред. Указа Президента Республики Беларусь от 28.02.2013 г. № 95) (далее - Указ № 691); Указ Президента Республики Беларусь от 18.10.2007 г. № 529 «О некоторых мерах по разви-
- рентабельность (реализованной продукции, продаж) $)^{13}$;

- добавленная стоимость в расчете на одного среднесписочного работника ${ }^{14}$;

- удельный вес отгруженной инновационной продукции в общем объеме отгруженной продукции ${ }^{15}$;

- срок реализации инвестиционного проекта ${ }^{16}$.

Критерии некоторых из представленных выше показателей утверждаются ежегодно в принимаемых постановлениях Совета Министров о реализации задач социально-экономического развития Республики Беларусь на очередной год. Однако нами не было зафиксировано ни одного факта прекращения предоставления государственной финансовой поддержки в результате несоответствия им, а тем более возврата денежных средств в бюджеты и внебюджетные фонды.

\section{Анализ отдельных форм господдержки при реализачии инвестищионных проектов в промышленности}

Нами проанализированы предприятия, которым была оказана индивидуальная государственная финансовая поддержка на реализацию инвестиционных проектов, на соответствие критерию показателя рентабельности (реализуемой продукции или продаж), устанавливаемого ежегодно. Данным предприятиям соответствующими Указами Президента Республики Беларусь ${ }^{17}$ было предусмотрено предоставление различных форм государственной финансовой поддержки. Полученные результаты представлены в табл. 3.

Данные свидетельствуют о том, что менее всего соответствовали установленному критерию рентабельности предприятия деревообрабатывающей промышленности. Многие из них демонстрируют уровни рен-

тию деревообрабатывающей промышленности» (в ред. Указа Президента Республики Беларусь от 03.04.2017 г. № 102) (далее - Указ № 529).

13 Там же; Указ Президента Республики Беларусь от 16.04.2012 г. № $174 \ll О$ некоторых мерах по развитию фармацевтической промышленности» (в ред. Указа Президента Республики Беларусь от 07.03.2017 г. № 63) (далее Указ № 174).

14 Постановление № 157.

15 Указ № 174 .

16 Там же.

17 Указ № 174; Указ № 529; Указ № 691. 


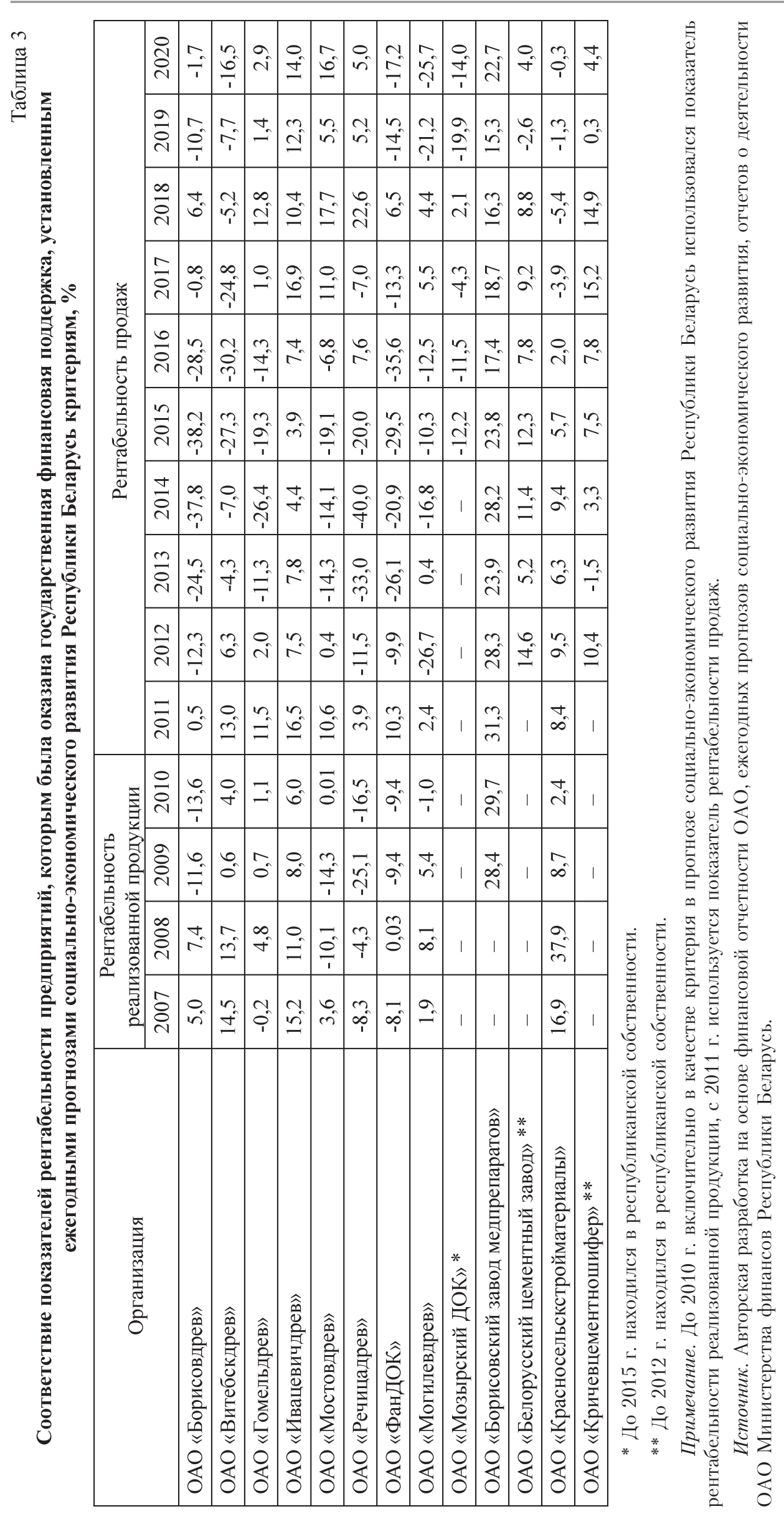


табельности не только ниже установленных показателей, но и отрицательные значения, что потребовало дополнительных прямых и косвенных форм поддержки данных предприятий со стороны государства. Единственным из анализируемых субъектов хозяйствования, соответствующих заданному критерию на протяжении всего анализируемого периода с начала реализации инвестиционного проекта, является ОАО «Борисовский завод медицинских препаратов».

Предприятия цементной промышленности также имеют периоды, когда фактические значения ниже нормативных. Как было отмечено выше, ни одного факта в приостановке оказания государственной финансовой поддержки нами не было выявлено.

Белорусским экономистом Е.В. Пресняковой отмечаются недостатки некоторых критериев, предъявляемых к инвестиционным проектам, претендующим на государственную поддержку: «анализ, основанный на финансовых документах за один отчетный период, недостаточен для оценки стабильности предприятия и перспектив его будущей деятельности, а статистическая надежность прогноза обеспечивается по меньшей мере данными за трехлетний период» (Преснякова, Матейчук, Зайцева, 2017).

Добавим, что плановые показатели не могут выступать в качестве основополагающих критериев, так как возможно оптимистическое смещение плановых показателей по проекту, а также их завышение с целью привлечения бюджетных денежных средств заинтересованными лицами.

Отличительной особенностью государственного финансового участия в реализации инвестиционных проектов является возможность предоставления различных форм государственной поддержки отдельным предприятиям Республики Беларусь на индивидуальной основе без заключения инвестиционного договора в рамках программ развития отдельных отраслей промышленности. К ним можно отнести предприятия деревообрабатывающей, стекольной, легкой, целлюлознобумажной, цементной и фармацевтической промышленностей. В табл. 4 представлены формы государственного финансового участия, применяемые для предприятий отдельных отраслей. Как видим, десяти предприя- тиям деревообрабатывающей промышленности было в совокупности предоставлено 10 форм государственной финансовой поддержки ${ }^{18}$, трем предприятиям цементной и двум целлюлозно-бумажной промышленности $9^{19}$, одному предприятию легкой промышленности $-7^{20}$, четырем предприятиям фармацевтической промышленности $-5^{21}$. Более того, нормативно-правовыми актами предусмотрено оказание таких форм государственной финансовой поддержки, которые другим предприятиям в рамках действующего законодательства не предоставляются: реструктуризация задолженности предприятия перед бюджетами различных уровней бюджетной системы, отсрочка по задолженности по платежам в ФСЗН Республики Беларусь с последующей рассрочкой погашения, налоговые кредиты и возмещение части расходов по уплате (возмещению) комиссий по открытию документарных аккредитивов.

Анализ государственной финансовой поддержки организаций Республики Беларусь проводился многими белорусскими экономистами (Матвеев, 2014; Гусаков, 2015; Рудый, 2016; Преснякова, Матейчук, Зайцева, 2017). Наиболее полная и детальная оценка была сделана Всемирным банком в 2010 г. по заказу Министерства финансов Республики Беларусь ${ }^{22}$. Однако существуют трудности в правильной оценке финансового участия государства в реализации инвестиционного проекта. Так, предоставление налоговых и неналоговых льгот в виде освобождения от уплаты налога или неналогового платежа, а также снижения налоговой ставки не отображается как форма государственной финансовой поддержки в официальной отчетности, составляемой Министерством финансов Республики Беларусь. До 2016 г. в Указе

\footnotetext{
18 Указ № 529 .

19 Указ Президента Республики Беларусь от 30.08.2012 г. № 391 « строительстве завода по производству сульфатной беленой целлюлозы» (в ред. Указа Президента Республики Беларусь от 31.12.2019 г. № 508) (далее - Указ № 391); Указ № 216; Указ № 691 .

20 Указ Президента Республики Беларусь от 31.12.2019 г. № 505 «Об организации производства суконных тканей в ОАО «Камволь» (далее - Указ № 505).

21 Указ № 174.

22 Винселетт Г.А., Эккард С. 2011. Обзор государственных расходов в Республике Беларусь. Вашингтон: Всемирный банк. 2 ч. URL: https://issuu.com/world. bank.publications/docs/belaruspublicexpenditurereview_rus
} 
Применение форм государственной финансовой поддержки реализации инвестиционных проектов на действующих промышленных предприятиях (на примере отдельных отраслей экономики)

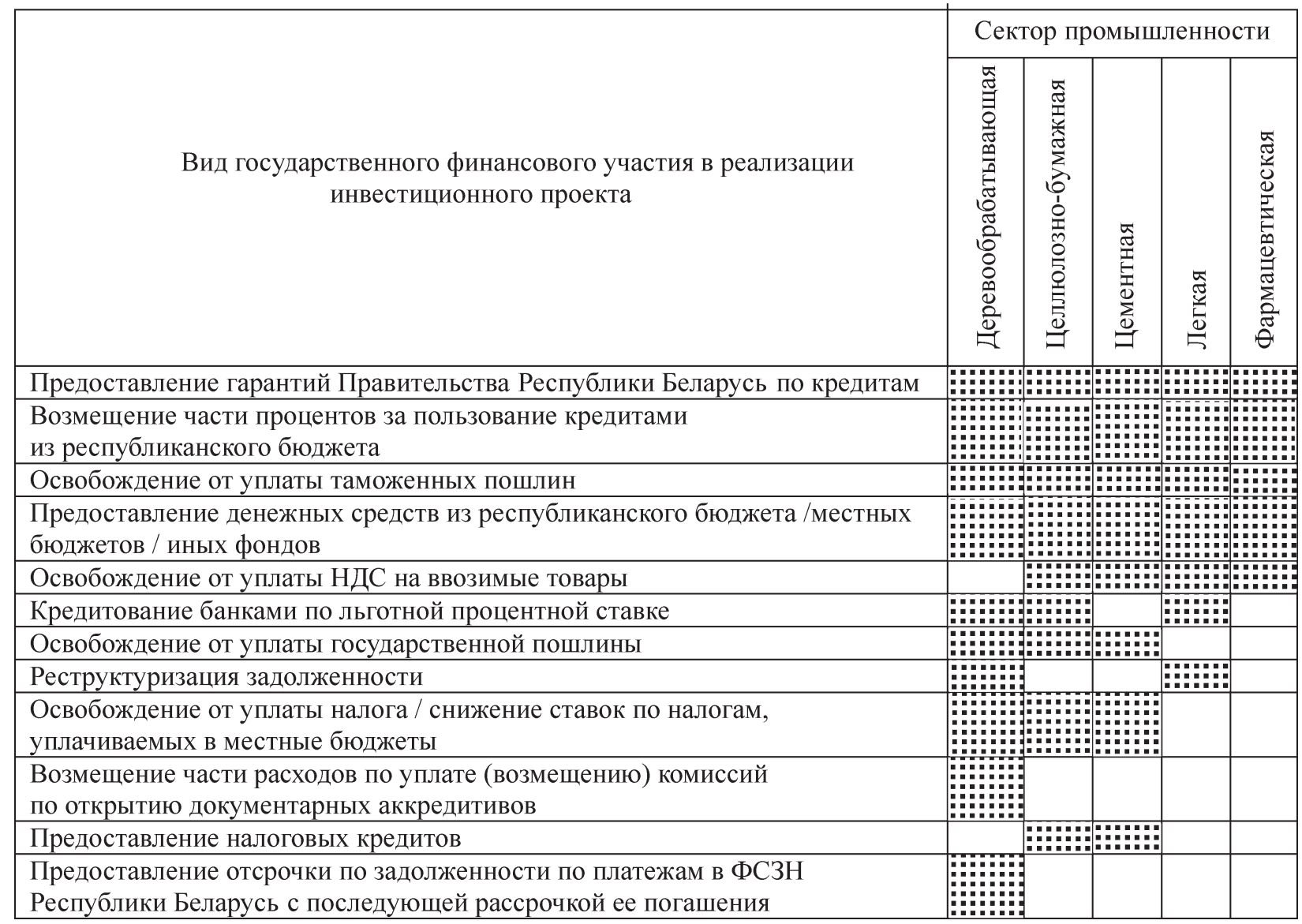

Источник. Указ № 174; Указ № 216; Указ № 391; Указ № 449; Указ № 505; Указ № 529; Указ № 691.

Президента Республики Беларусь № 182 цели получения государственной финансовой поддержки не ограничивались только реализацией инвестиционного проекта, однако данные по структуре форм государственной поддержки по целям не приводятся.

Учитывая перечисленные выше особенности, оказывающие влияние на качество информационной базы финансового участия государства в реализации инвестиционных проектов, рассмотрим некоторые практики предоставления финансовой поддержки в рамках отдельных законодательных актов. В частности, Указом Президента Республики Беларусь № 168 от 21.03.2008 г. определяется, какие формы государственной финансовой поддержки могут быть оказаны предприятиям, которые реализуют инвестиционный проект за счет внешних займов и внешних займов, привлеченных под гарантии Правительства Республики Беларусь. Нами был проанализирован перечень инвестиционных проектов, финансируемых таким способом. Из 35 включенных в перечень ${ }^{23}$ проектов только 10 (на 9 предприятиях) являются коммерческими, все остальные были отнесены нами к инфраструктурным и не рассматривались. В табл. 5 представлены формы государственной финансовой поддержки предприятий.

Следует отметить, что данным Указом предусмотрено предоставление только четырех форм государственного финансового участия в реализации проекта: освобож-

${ }_{23}^{23}$ Постановление Совета Министров Республики Беларусь от 04.05.2009 г. № 572 «Об утверждении перечня финансируемых за счет внешних государственных займов и внешних займов, привлеченных под гарантии Правительства Республики Беларусь, инвестиционных проектов и предназначенных для реализации таких проектов технологического оборудования и запасных частей к нему, которые при ввозе на территорию Республики Беларусь освобождаются от таможенных пошлин и налога на добавленную стоимость» (в ред. постановления Совета Министров Республики Беларусь от 07.02.2020 г. № 79) (далее - постановление № 572). 
Формы государственной финансовой поддержки предприятий, инвестиционные проекты которых включены в перечень финансируемых за счет внешних госзаймов и внешних займов, привлеченных под гарантии Правительства Республики Беларусь

\begin{tabular}{|c|c|c|c|c|c|c|c|c|c|}
\hline \multirow[b]{3}{*}{ Предприятие } & \multirow[b]{3}{*}{ 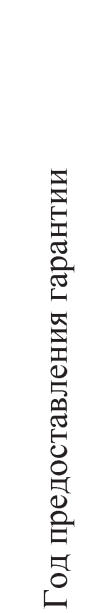 } & \multicolumn{8}{|c|}{ Формы поддержки } \\
\hline & & \multicolumn{3}{|c|}{ Прямые } & \multicolumn{5}{|c|}{ Косвенные } \\
\hline & & 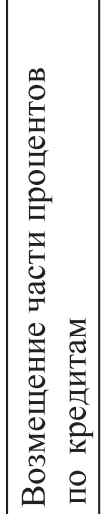 & 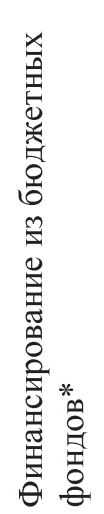 & 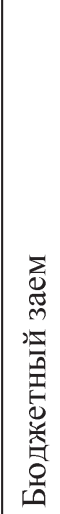 & 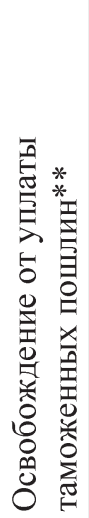 & 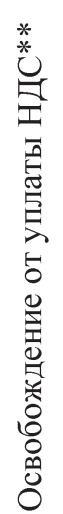 & 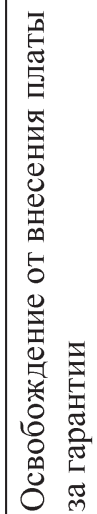 & 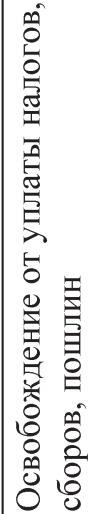 & 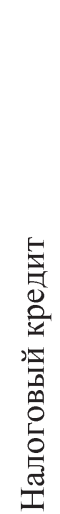 \\
\hline ОАО «Светлогорск Химволокно» & 2008 & & & & :m & I:Ai & & & \\
\hline ОАО «Минский тракторный завод» (МТЗ) & 2008 & & & & int & IIII & & & \\
\hline ОАО «Белорусский цементный завод» (БЦЗ) & 2008 & :\#: & I:1: & & & & $\mathrm{At}$ & & :A: \\
\hline ОАО «Кричевцементношифер» (КЦШ) & 2008 & & ::\# & & & & & & \\
\hline ОАО «Красносельскстройматериалы» (КСМ) & 2008 & ::a & :a: & & & & & & \\
\hline ОАО «Светлогорский ЦКК» (СЦКК) & $\begin{array}{l}2010, \\
2012\end{array}$ & & & & & & & & \\
\hline $\begin{array}{l}\text { «Добрушская бумажная фабрика «Герой труда» } \\
\text { («Герой труда») }\end{array}$ & 2011 & & & & & :\#: & & & \\
\hline РУП «Завод газетной бумаги» (ЗГБ) & 2012 & :D:-1: & & & Ha: & A: & & & \\
\hline СЗАО «БЕЛДЖИ» & 2015 & & 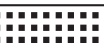 & & :a:a: & :a: & & & \\
\hline
\end{tabular}

* Источники финансирования - фонд национального развития Республики Беларусь, республиканский и местные инновационные фонды.

** При ввозе оборудования и запасных частей к нему на территорию Республики Беларусь.

Источник. Указ Президента Республики Беларусь от 16.01.2014 г. № 35 « вопросах организации производства легковых автомобилей» (в ред. Указа Президента Республики Беларусь от 03.12 .2015 г. № 479) (далее Указ № 35); постановление Совета Министров Республики Беларусь от 19.08.2009 г. № 1084 «О некоторых мерах по реализации инвестиционного проекта республиканским унитарным предприятием «Светлогорское производственное объединение «Химволокно» (далее - постановление № 1084); Указ № 216;Указ № 449; Указ № 691; постановление № 157; постановление № 572 .

дение от уплаты таможенных пошлин и налога на добавленную стоимость (далее НДС) при ввозе оборудования и запасных частей к нему на территорию Республики Беларусь; освобождение от внесения платы за гарантии; возмещение $50 \%$ от суммы процентных платежей по внешним займам и ограничение маржи банка ${ }^{24}$.

Исходя из представленных сведений можно заметить, что предприятиям были также предоставлены индивидуальные формы государственной финансовой поддержки, такие как финансирование из бюджетных фондов, предоставление бюджетных займов, ос-

\footnotetext{
24 Указ № 168.
}

вобождение от уплаты налогов, сборов, пошлин, а также налоговые кредиты.

Нами была проанализирована структура форм государственной финансовой поддержки данных предприятий исходя из деления их на прямые и косвенные. Так, определены суммы денежных средств, направляемых на предоставление различных форм поддержки предприятия из бюджетов и бюджетных фондов и оценены суммы денежных средств, которые недопоступили в бюджеты в результате предоставления таких форм, как освобождение от внесения платы за гарантии Правительства Республики Беларусь, освобождение от уплаты таможенных пошлин и НДС, иных 
налогов и сборов. Исходя из полученных данных была определена структура форм государственной поддержки. Полученные результаты представлены на рис. 1.

В целом по 9 анализируемым предприятиям доля финансирования за счет прямого участия в реализации проекта составляет $77,9 \%$. В то же время отдельным организациям были предоставлены только косвенные формы государственной финансовой поддержки - освобождение от уплаты НДС и таможенных пошлин при ввозе на территорию Республики Беларусь оборудования, приобретаемого в рамках реализации инвестиционного проекта (ОАО «Светлогорск Химволокно», ОАО «МТЗ»), что привело к недопоступлению денежных средств в бюджеты на сумму налогов и платежей. Наряду с этим, по остальным предприятиям сохраняется преобладание прямого финансирования в структуре государственной поддержки.

В соответствии с Указом № 182 одной из форм государственной финансовой поддержки до 2016 г. являлось возмещение части процентов за пользование кредита- ми на условиях конкурсного размещения. С 2012 по 2015 г. постановлениями Совета Министров Республики Беларусь ежегодно принимались нормативно-правовые акты с перечнем предприятий, которым возвращается из средств республиканского бюджета часть процентов за пользование банковскими кредитами. Следует отметить, что в рамках данного Указа предусматривалось возмещение процентов по кредитам не только коммерческим, но и инфраструктурным проектам. За весь период с 2012 по 2015 г. доля коммерческих проектов была наибольшей по сравнению с инфраструктурными и оставалась практически неизменной даже при сокращении количества финансируемых предприятий.

Исчерпывающая статистическая информация о суммах и структуре исполненных гарантий Правительства Республики Беларусь или местных исполнительных и распорядительных органов не предоставляется. Несмотря на то, что последние годы Министерством финансов Республики Беларусь проводится политика ограничения

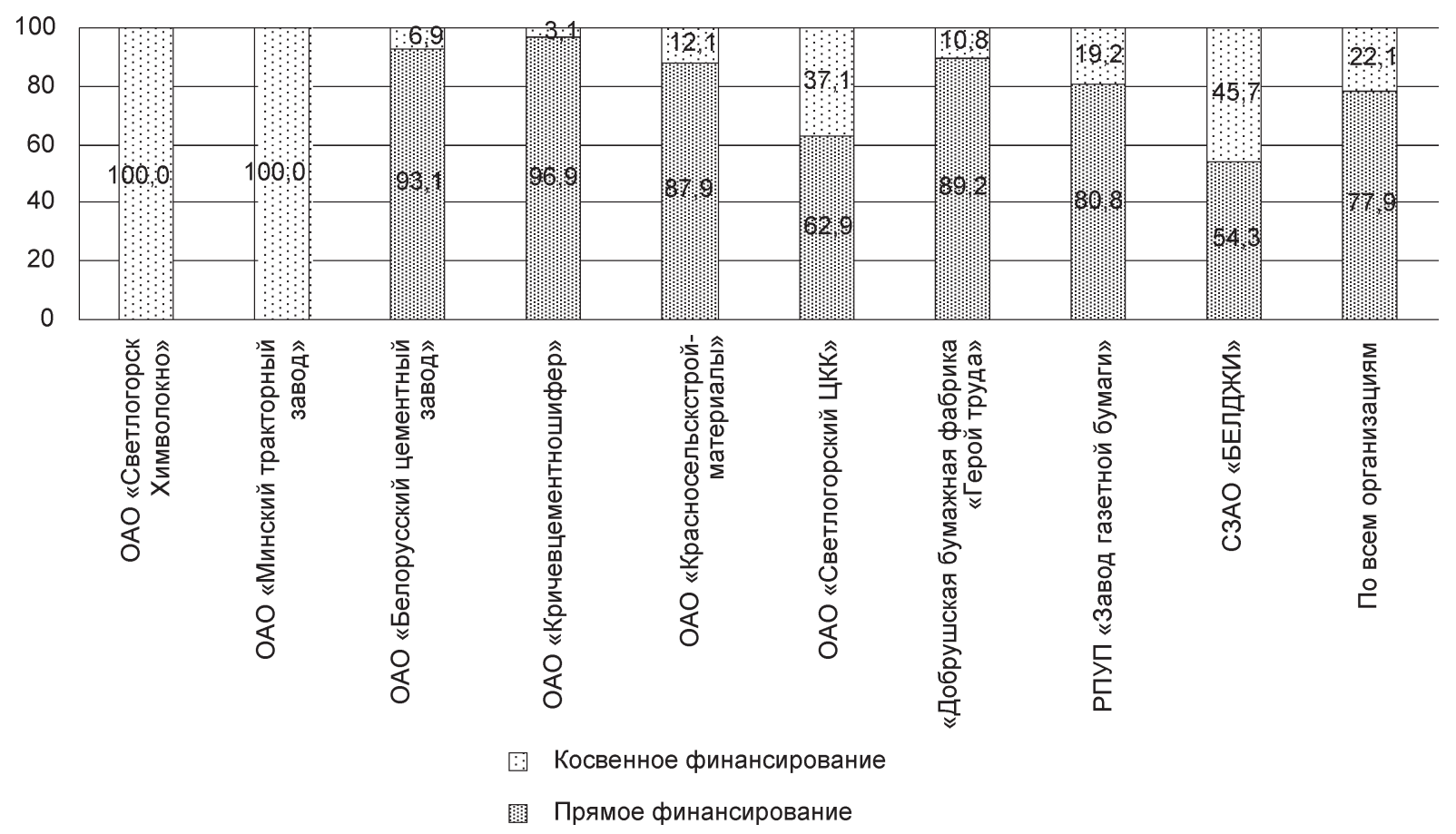

Рис. 1. Структура государственной финансовой поддержки инвестиционных проектов предприятий за счет внешних государственных займов и внешних займов, привлеченных под гарантии Правительства Республики Беларусь, \%

Источник. Указ № 35; Указ № 216; Указ № 449; Указ № 691; постановление № 157; постановление № 572; постановление № 1084; постановление № 1718. 
выдачи гарантий по привлеченным кредитам для реализации инвестиционных проектов, тем не менее существующие обязательства Правительства Республики Беларусь создают существенные фискальные риски, что в лучшем случае может привести к увеличению запланированных расходов бюджета на исполнение гарантий по кредитам как внешним, так и внутренним ${ }^{25}$.

Возникновение данной ситуации обусловлено рядом причин (Голикова, 2017):

1) в соответствии с Законом о республиканском бюджете устанавливается максимально возможная ставка единовременной платы за предоставление государственной гарантии, равная 1,5\% от суммы кредита, выданного банком, что позволяет взимать минимальную плату (например, 0,01\% для предприятий целлюлозно-бумажной промышленности ${ }^{26}$ ) или освобождать от осуществления платы за предоставленную гарантию Правительства Республики Беларусь отдельные организации (например, с предприятий деревообрабатывающей $^{27}$ и цементной ${ }^{28}$ промышленности плата не взималась);

2) гарантии, предоставлявшиеся до 2016 г., покрывали всю сумму выданного кредита и процентов по нему, в результате риски полностью переносились с кредитополучателя и кредитора на государственный бюджет Республики Беларусь, а следовательно, и налогоплательщиков страны;

3) не осуществлялся открытый конкурсный отбор предприятий, претендовавших на получение государственной гарантии по кредиту, выданному на реализацию инвестиционного проекта;

4) оценка риска исполнения обязательств по выданным гарантиям Правительства и местных исполнительных и распорядительных органов не проводилась, анализ платежеспособности предприятия осуществлялся в соответствии с Правилами по разработке бизнес-

25 Тезисы доклада Министра финансов Республики Беларусь Амарина Владимира Викторовича на расширенном заседании Министерства финансов Республики Беларусь по вопросу «Об итогах исполнения бюджета Республики Беларусь за 2015 год и задачах финансовых органов на 2016 год». URL: http://www.minfin.gov.by/upload/ministerstvo/ kollegii/doklad_ministra_19022016.pdf; Бюджетное равновесие. Расширенная коллегия Минфина. 2017. Финансы. Учет. Аудит. № 3. С. 7-14.

\footnotetext{
26 Указ № 391

27 Указ № 529 .

28 Указ № 691 .
}

планов инвестиционных проектов на основе показателей эффективности;

5) несмотря на законодательное ограничение предоставления гарантий Правительства Республики Беларусь предприятиям, имеющим задолженность по платежам в республиканский и местные бюджеты, к отдельным предприятиям данное условие не применялось.

Таким образом, перечисленные выше особенности позволяют заключить о возникновении достаточно высокого фискального риска по исполнению обязательств перед кредиторами по государственным гарантиям, предоставленным по кредитам, выданным банками и внешними кредиторами на реализацию инвестиционных проектов.

Проведенный анализ был бы неполным, если не упомянуть используемые в 20152016 гг. финансовые схемы государственной помощи отдельным предприятиям, не предусмотренные законодательством, но оказавшие влияние на состояние государственного долга Республики Беларусь. Так, в 2015 г. на сумму 1,4 млрд долл. США и 1,4 трлн бел. руб. были эмитированы государственные облигации для поддержки промышленных предприятий и приобретения проблемных кредитов деревообрабатывающих предприятий, в 2016 г. для стабилизации деятельности отдельных валообразующих организаций проведена реструктуризация кредитной задолженности, возникшей в результате реализации инвестиционных проектов, за счет средств республиканского бюджета ${ }^{29}$.

\section{Особенности и проблемы господдержки инвестиционных проектов в промыииленности и подходы к ее рационализации}

Дополнительная господдержка в последние годы потребовалась практически всем предприятиям, реализовавшим крупные инвестиционные проекты в процессе сплошной модернизации отдельных отраслей для их завершения или устранения выявленных недостатков. В то же время

29 Указ Президента Республики Беларусь от 24.06.2015 г. № 257 «О некоторых вопросах приобретения активов банков, сформированных при кредитовании организаций деревообрабатывающей промышленности, и уточнении лимита внутреннего государственного долга» (в ред. от 20.01.2020 г. № 20). 
продолжение финансовой поддержки продолжилось из-за того, что после введения производственных мощностей модернизированные предприятия оказались в сложном финансовом положении из-за необходимости обслуживания привлеченных под реализацию инвестпроектов кредитов (преимущественно валютных) в условиях существенного ухудшения внешнеторговой конъюнктуры. Одновременно точечная финансовая поддержка со стороны государства оказывалась реализуемым или вновь начинаемым инвестиционным проектам и в других отраслях промышленности.

В свою очередь, государственная финансовая поддержка осуществлялась посредством как использования традиционных форм за счет средств бюджетных и внебюджетных фондов, так и директивного целевого кредитования банками с компенсацией разницы процентных ставок. При этом возрастала роль Банка развития, который одновременно предпринял ряд мер по постепенному изменению и рационализации подходов по предоставлению кредитных ресурсов приоритетным отраслям и секторам белорусской экономики.

Различные традиционные формы государственной финансовой поддержки в последние годы оказывались государственным предприятиям практически всех отраслей промышленности (цементной, деревообрабатывающей, стекольной, целлюлозно-бумажной, легкой, пищевой, машиностроительной, металлургической и др.).

Решения об условиях государственной поддержки конкретных коммерческих предприятий и холдингов принимались на основе соответствующих указов президента и постановлений правительства. При этом отдельные из этих документов в последнее время отмечены грифом «для служебного пользования», что затрудняет их количественный анализ, особенно в части их результативности.

Среди основных форм государственной финансовой поддержки в промышленности можно отметить следующие: отсрочки и рассрочки в части погашения бюджетных займов и банковских кредитов, а также процентных ставок, которые будут погашаться за счет средств республиканс- кого бюджета; предоставление новых бюджетных займов и банковских кредитов на льготных условиях; освобождение от уплаты отдельных налогов на продолжительное время (земельный, на недвижимость, акцизов, на прибыль), таможенных пошлин и платежей; финансирование за счет средств инновационного фонда; передача акций в собственность государства на сумму оказанной господдержки, приобретение банками акций после их дополнительной эмиссии и выпущенных корпоративных облигаций; предоставление гарантий по кредитам правительством, местными органами управления и государственными банками; обеспечение гарантированного сбыта части продукции; предоставление отсрочек по расчетам за топливно-энергетические ресурсы. Одновременно ведущим системообразующим банкам предоставлены соответствующие дополнительные ресурсы для кредитования госсектора.

Наиболее существенную государственную финансовую поддержку в последние годы приходится оказывать предприятиям тех отраслей, в которых провели масштабную модернизацию. К ним в первую очередь можно отнести цементную, деревообрабатывающую, целлюлозно-бумажную и стекольную отрасли. Так, в соответствии с Указом Президента Республики Беларусь № 181 от 16 мая 2020 г. предоставлена очередная господдержка модернизированным цементным заводам посредством отсрочки и рассрочки по расчетам с бюджетом и налоговых льгот.

Как известно, модернизацию 3-х цементных заводов начали еще в 2007 г. и предполагали к 2010 г. завершить. Вместе с тем сроки модернизации затянулись, и на нее в течение 2008-2013 гг. было потрачено порядка 1,2 млрд долл. США. При этом в 2015-2019 гг. долги обслуживались за счет республиканского бюджета. В результате погашение образовавшейся задолженности цементных заводов перед бюджетом отсрочили до 2029-2049 гг. В частности, долги и проценты по ним ОАО «Белорусский цементный завод» будет возвращать в 20292038 гг., ОАО «Кричевцементношифер» в 2038-2049 гг., ОАО «Красносельскстройматериалы» - в 2030-2037 гг. 
Кроме того, указом предусмотрено, что Банк развития и ОАО «АСБ Беларусбанк» оформят рассрочку по 31.12. 2024 г. по погашению задолженности в части основной суммы долга по кредитам ОАО «Красносельскстройматериалы», по 31.12. 2026 г. ОАО «Белорусский цементный завод» и ОАО «Кричевцементношифер». В свою очередь, ОАО «Белинвестбанк», ОАО «Банк БелВЭБ» и ЗАО Банк ВТБ (Беларусь) предоставят отсрочку ОАО «Красносельскстройматериалы» до 1.01.2025 г. и рассрочку по 31.12.2029 г. по погашению образовавшейся на 1.01.2019 г. задолженности. При этом проценты по кредитам белорусским банкам будут до 31.12. 2026 г. уплачиваться за счет средств республиканского бюджета.

Из других мер поддержки, представленных в данном указе, можно отметить следующие. Предприятия цементной отрасли освобождены от налога на недвижимость и земельного налога: с 1.01.2019 г. по 31.12.2037 г. ОАО «Красносельскстройматериалы», по 31.12.2038 г. - ОАО «Белорусский цементный завод» и по 31.12.2049 г. - ОАО «Кричевцементношифер». Они также получают от Минэнерго рассрочку по погашению задолженности за природный газ.

Одновременно в указе определены и отдельные критерии получения господдержки, включая достижение доведенных показателей по росту производительности труда, рентабельности продаж, прибыли от реализации товаров (работ, услуг) и загрузке производственных мощностей.

Поддержка цементной отрасли осуществляется также посредством обеспечения гарантированного сбыта части продукции для подчиненных республиканским и местным органам управления организаций (включая строительство транспортной инфраструктуры), что предусматривается Постановлением Совмина № 99 от 19 февраля 2020 г., исходя из которого равномерная поставка цемента в течение года должна составить 3,462 млн т.

Что касается 2021 г., то 15 февраля было принято Постановление Совмина № 83, в соответствии с которым проценты по кредитам 3-м цементным предприятиям и ОАО «Гродненский стеклозавод», которые выданы Банком развития и ОАО «АСБ
Беларусбанк», покроются в текущем году за счет республиканского бюджета. При этом предусмотрены следующие условия. По кредитам в белорусских рублях цементным заводам будут компенсироваться из бюджета проценты на уровне ставки рефинансирования, а по валютным - в размере ставки, не превышающей $7 \%$ и с учетом пересчета в белорусские рубли. По рублевым кредитам для ОАО «Гродненский стеклозавод» компенсация составит половину ставки рефинансирования, по валютным половину ставки с уплатой в белорусских рублях. Высвободившиеся таким образом денежные ресурсы стеклозаводом будут направлены на пополнение оборотных средств.

В отношении ОАО «Стеклозавод «Неман» еще 24 апреля 2020 г. принят Указ № 144, в котором предусматривается освобождение от уплаты налога на недвижимость и земельного налога с 1.04.2020 г. по 31.12.2044 г. Одновременно предприятию предоставлена возможность реструктурировать сформировавшуюся на 1.05.2020 г. задолженность перед ОАО «Белагропромбанк» посредством допэмиссии акций или предоставления отсрочки до 1.01.2041 г. и рассрочки с 1.01.2041 г. по 31.12.2044 г. Часть объектов недвижимости предполагается передать Лидскому району.

Особо следует остановиться на продолжении достаточно затратной и затянувшейся по срокам модернизации целлюлознобумажной и деревообрабатывающей отраслей. Наиболее масштабные инвестиционные проекты здесь - строительство завода по производству сульфатной беленой целлюлозы ОАО «Светлогорский ЦКК» и комплекса по производству картона на Добрушской бумажной фабрике «Герой труда».

Завод по производству сульфатной беленой целлюлозы ОАО «Светлогорский ЦКК» начали строить в 2010 г. и планировали ввести в 2015 г. В целом стоимость строительства составила порядка 770 млн долл. США, и до последнего времени по китайскому кредиту рассчитывался Минфин. В конечном счете в 2019 г. был расторгнут контракт с китайским генподрядчиком CAMCE, а завершение строительства ОАО «Светлогорский ЦКК» осуществлял 
совместно с отечественными подрядными организациями.

Аналогичная ситуация сложилась при реализации второго проекта с привлечением китайского кредита в объеме 350 млн долл. США сроком на 13 лет. Первоначальные сроки реализации (2015 г.) неоднократно переносились, а контракт с китайской корпорацией «Сюань Юань» был расторгнут еще в 2018 г. Указом Президента Республики Беларусь № 44 от 10.02.2020 г. «Об инвестиционном проекте» было дополнительно выделено 80 млн долл. США для завершения проекта по производству мелованных и немелованных видов картона, половина из которых поступит австрийской компании Andritz. На проектную мощность предполагается выйти только в 2023 г.

В соответствии с Государственной программой «Белорусский лес» на 2021-2025 гг., активная модернизация целлюлозно-бумажной и деревообрабатывающей отраслей продолжится с выделением около 2,6 млрд руб. (порядка 1 млрд долл. США). При этом часть средств - из бюджета (около 300 млн руб. в 2021-2022 гг. - на погашение внешних государственных займов и 172 млн руб. - возмещение процентов). В качестве основного источника реализации инвестиционных проектов предусматривается привлечение кредитов в сумме 1,8 млрд руб. Основная часть средств уйдет на создание производства упаковочных материалов на ОАО «Светлогорский ЦКК» с литовской компанией VMG и приобретение для этого соответствующего оборудования. Ряд проектов будет реализован в деревообработке.

В последние годы была оказана государственная финансовая поддержка при реализации ряда инвестиционных проектов и в других отраслях промышленности (машиностроение, легкая, пищевая, химическая и нефтехимическая и др.), что нашло отражение в соответствующих нормативно-правовых актах. В частности, 31.01.2020 г. принято Постановление Совмина № 55 об оказании господдержки из бюджета отдельным предприятиям легкой промышленности: ОАО «Камволь», ОАО «БХПО» и РУПТП «Оршанский льнокомбинат».

В качестве форм господдержки используются также повышение доли государства в акционерном капитале отдельных предприятий (например, в цементной, деревообрабатывающей и стекольной отраслях в соответствии с постановлениями Совмина № 222 от 14.04.2020 г. и № 301 от 2.06.2021 г.) или покупка банками корпоративных облигаций некоторых предприятий (в частности, БМЗ и БелАЗа) или акций (ОАО «Белшина»).

Одновременно можно отметить примеры успешной реализации ряда инвестиционных проектов с финансовой поддержкой государства. В частности, к ним можно отнести фармацевтические, нефтехимические и химические предприятия. Однако необходимо принимать во внимание, что с повышением цен на российские энергоносители и с учетом существующей для белорусских НПЗ логистики в дальнейшем на данных предприятиях могут возникнуть проблемы.

В целом объемы господдержки существенно увеличиваются как в годы реализации масштабных программ сплошной модернизации целых отраслей (в частности, в 2012-2014 гг.), так и через дополнительную поддержку предприятий по причине затягивания сроков (до 3 лет и более) выполнения данных проектов и чрезмерно оптимистичных оценок стоимости и эффективности реализуемых инвестпроектов. При этом данная ситуация усугубляется из-за их недостаточной маркетинговой проработки, связанной как с ухудшением внешнеторговой конъюнктуры, так и в целом макроэкономической ситуации в стране.

В качестве основных макроэкономических факторов, оказавших негативное влияние на эффективность реализации инвестиционных проектов с государственной финансовой поддержкой, следует отметить: периодическую и существенную девальвацию белорусского рубля; высокую инфляцию в Беларуси на протяжении длительного времени и, как следствие, высокие процентные ставки по кредитам; девальвацию отдельных иностранных валют (в частности, российского рубля в 2014 г.) и периодическое ухудшение конъюнктуры на традиционных рынках сбыта высокоэластичной продукции модернизированных предприятий. 
Решения об оказании государственной финансовой поддержки в реализации большинства инвестиционных проектов пронимались в 2007-2008 гг.: период, когда колебания курса белорусского рубля по отношению к иностранным валютам были незначительны. Многие предприятия финансировали приобретение оборудования за счет кредитов, выданных в иностранной валюте, некоторые прибегали к внешним займам, привлеченным под гарантии Правительства Республики Беларусь. Естественно, даже если и проводился анализ чувствительности и сценариев, то влияние значительного снижения стоимости национальной денежной единицы не рассматривалось. Разовая девальвация, проведенная в начале 2009 г., привела к увеличению требуемых сумм по погашению основного долга и процентов по кредитам, привлеченным для реализации инвестиционных проектов, а также по оплате сырья и материалов, импортируемых для производства продукции. Значительное влияние оказала также девальвация белорусского рубля, имевшая место в 2011 г.: помимо снижения стоимости национальной валюты почти в три раза по отношению к началу года, было замедлено принятие Национальным банком Республики Беларусь эффективных мер, что привело к дефициту валютных средств, торгуемых на Белорусской валютно-фондовой бирже. Резкое снижение стоимости российского рубля в конце 2014 г. оказало влияние и на белорусский рубль, девальвация которого продолжилась и в 2015 г. К тому же в 2020 г. белорусский рубль девальвировался почти на $35 \%$ к евро и $23 \%$ к доллару США.

Дальнейшее снижение стоимости национальной валюты ухудшало финансовое положение импортозависимых организаций, а также кредитополучателей, финансирующих проекты за счет займов, которые получены в иностранной валюте.

Снижение стоимости национальной валюты также повлияло и на суммы предоставляемой государственной финансовой поддержки. Так, обязательства государства по возмещению части процентов по кредитам, предоставленным в иностранной валюте, привели к необходимости увеличе- ния сумм при сохранении той же доли погашаемых за счет бюджета средств.

Негативное влияние высоких и труднопрогнозируемых темпов инфляции, переменных по времени и неоднородных по видам продукции, со значительной долей девальвационной составляющей, проявляется прежде всего в том, что при реализации такого сценария развития событий рост расходов на производство продукции увеличивается быстрее, чем рост выручки от реализации, что уменьшает сумму получаемой прибыли организации.

Следует также отметить, что в условиях высокой инфляции и рисков выросли процентные ставки по кредитам, предоставляемым белорусскими банками. Как можно заметить, в 2007-2010 гг. в результате проводимой денежно-кредитной политики ставки по кредитам в национальной валюте колебались в пределах от 3,4 до 16,2\% по долгосрочным кредитам и от 12 до $20,9 \%$ - по краткосрочным. С середины 2011 г. процентная ставка по кредитам на период менее 1 года превысила максимальное значение предыдущих лет и достигла пика в январе 2012 г., составив 55,3\%. Процентная ставка по кредитам на срок свыше 1 года была максимальной в январе, составив 41,2\%. В целом за 2011-2015 гг. средние процентные ставки по краткосрочным и долгосрочным кредитам составили 35 и $22,6 \%$ соответственно. Предприятия, которые только осуществили запуск новых производственных линий, нуждались в финансировании оборотных средств из-за дефицита собственных. Взимаемые банками проценты за пользование кредитами значительно сокращали суммы получаемых доходов предприятий, вынуждая прибегать к новому краткосрочному кредиту. Определенную роль сыграло и директивное кредитование, позволявшее предприятиям получать банковские кредиты по льготным процентным ставкам, что также привело к высоким рыночным процентным ставкам на финансовом рынке.

В свою очередь, в силу ряда политических и экономических причин на протяжении 2014-2015 гг. отмечалось снижение стоимости российского рубля, сопровождавшееся периодами резкого падения курса (напри- 
мер, 15-16 декабря 2014 г.) и восстановления своих позиций. По итогам 2014 г. стоимость российского рубля к доллару США снизилась на 58\%, в 2015 г. - на 27\%. Данная ситуация сопровождалась рядом событий:

снижением деловой активности в Российской Федерации, которая является основным торговым партнером Республики Беларусь, что привело к уменьшению объемов реализации по отдельным товарным позициям;

распространением валютного кризиса на ряд других постсоветских стран, экономика которых тесно связана и зависит от Российской Федерации, что привело к снижению конкурентоспособности белорусских товаров на зарубежных рынках стран, девальвировавших валюты, а также уменьшению объемов получаемой выручки.

Создавшаяся ситуация не позволила белорусским предприятиям достигнуть запланированных показателей по реализации продукции и, как следствие, по полученной выручке и прибыли, что негативно отразилось и на финансовом положении, и на способности обслуживать привлеченные для реализации инвестиционных проектов кредиты.

Кроме того, в Республике Беларусь в отдельные годы проводилась экспансионистская макроэкономическая и монетарная политика по чрезмерному стимулированию внутреннего потребительского и, особенно, инвестиционного спроса, что усилило дисбалансы в экономическом развитии страны и макроэкономическую нестабильность и привело к существенным девальвациям валютного курса белорусского рубля и высокой инфляции на протяжении длительного периода. В результате был искусственно создан дополнительный внутренний спрос на определенные виды продукции, сократился ее экспорт. В дальнейшем с целью расширения производственных мощностей было принято недостаточно обоснованное решение о сплошной, а не точечной модернизации целых отраслей (цементной, стекольной, деревообрабатывающей). Однако в последующие годы внешняя и внутренняя конъюнктура на высокоэластичные товары существенно ухудшилась, что привело к недозагрузке модернизированных мощностей (вместо дефицита возник их профицит) при возросшей для предприятий нагрузке по погашению кредитов (преимущественно в валюте). Одновременно в Российской Федерации в последние годы активно реанимируются и строятся аналогичные производства, которые с учетом более дешевых факторов производства успешно конкурируют с белорусскими предприятиями (Матяс, 2017).

Правительством и Министерством финансов Республики Беларусь применяются меры по уменьшению выделяемых из бюджетов и внебюджетных фондов сумм государственной финансовой поддержки неэффективным предприятиям и нежизнеспособным инвестиционным проектам и снижению фискальных рисков для государственного бюджета, в том числе за счет сокращения количества форм государственной финансовой помощи, введения дополнительных критериев и конкурсного подхода. Однако у Правительства Республики Беларусь по отдельным проблемным предприятиям существуют обязательства до 2029 г. (организации деревообработки), что окажет влияние на состояние государственных финансов на ближайшие годы.

Особо следует отметить возросшую в последние годы роль Банка развития в финансировании инвестиционных проектов. При этом данный банк предоставляет кредиты предприятиям, инвестиционные проекты которых включены в государственные программы с наиболее значимыми для страны проектами, основанием для финансирования которых являются решения Президента Республики Беларусь. Банк также самостоятельно отбирает проекты по соответствию их требованиям инновационности, возможностям импортозамещения и увеличения экспорта, а также развития приоритетных для страны видов деятельности.

Все инвестиционные проекты проходят обязательную экспертизу, направленную на оценку экономической эффективности и финансовой реализуемости проекта.

С 2016 г. за счет средств Банка развития предусмотрено частичное финансирование девяти государственных программ, а также кредитование проектов на промышленных предприятиях в рамках трех программ. Объемы 
кредитования и доля участия в реализации государственных программ Банком развития представлены в табл. 6.

В целях постепенного снижения директивного кредитования Правительством Республики Беларусь ежегодно с 2016 г. устанавливаются его лимиты для Банка развития и других банков Беларуси. Программой социально-экономического развития Республики Беларусь на 2016-2020 гг. предусматривалось, что к концу пятилетия Банк развития станет единственным каналом льготного кредитования всех государственных программ. Однако в 2020 г. объем директивного кредитования банками существенно вырос в связи с принятием Президентом Республики Беларусь, правительством и местными органами власти ряда решений, направленных на обеспечение стабильной работы экономики в связи с пандемией коронавируса. В табл. 7 представлены суммы льготных кредитов, предоставленных Банком развития Республики Беларусь в рамках директивного кредитования, а также его доля в общем объеме выданных кредитов банков.

Финансирование направлено главным образом на инфраструктурные, социальные

Финансирование Банком развития государственных программ, 2016-2020 гг.

Таблица 6

\begin{tabular}{|c|c|c|c|}
\hline \multirow{2}{*}{\multicolumn{2}{|c|}{ Государственная программа }} & \multicolumn{2}{|c|}{ Объем финансирования } \\
\hline & & \multirow{2}{*}{ млн руб. } & \multirow{2}{*}{$\begin{array}{c}\text { Доля в финансировании } \\
\text { за счет всех источников, \% } \\
4,3 \\
\end{array}$} \\
\hline \multirow{5}{*}{$\begin{array}{l}\text { Государственная программа инновационного } \\
\text { развития Республики Беларусь на 2016-2020 гг. }\end{array}$} & 2016 & & \\
\hline & 2017 & 68,8 & 3,1 \\
\hline & 2018 & 126,9 & 4,2 \\
\hline & 2019 & 176,0 & 8,7 \\
\hline & 2020 & 201,5 & 8,5 \\
\hline \multirow{5}{*}{$\begin{array}{l}\text { Государственная программа развития } \\
\text { аграрного бизнеса в Республике Беларусь } \\
\text { на 2016-2020 гг. }\end{array}$} & 2016 & 88,5 & 2,0 \\
\hline & 2017 & 102,7 & 2,2 \\
\hline & 2018 & 98,7 & 1,9 \\
\hline & 2019 & 185,5 & 2,4 \\
\hline & 2020 & 127,6 & 1,2 \\
\hline \multirow{2}{*}{$\begin{array}{l}\text { Государственная программа развития } \\
\text { машиностроительного комплекса Республики } \\
\text { Беларусь на 2017-2020 гг. }\end{array}$} & 2019 & 566,7 & 30,4 \\
\hline & 2020 & 699,9 & 32,8 \\
\hline
\end{tabular}

Источник. Авторская разработка на основе аналитических отчетов Банка развития Республики Беларусь за 2016-2020 гг.

Участие Банка развития в директивном кредитовании промышленности, 2016-2020 гг.

\begin{tabular}{|l|c|c|c|}
\hline \multirow{2}{*}{$\begin{array}{l}\text { Отрасли, финансируемые за счет директивного } \\
\text { кредитования }\end{array}$} & \multicolumn{2}{|c|}{ Директивное кредитование } \\
\cline { 3 - 4 } \multicolumn{2}{|c|}{} & млн руб. & $\begin{array}{c}\text { Доля в общем объеме выданных } \\
\text { директивных кредитов, \% }\end{array}$ \\
\hline Предприятия агропромышленного комплекса & 2016 & 88,5 & 57,6 \\
\cline { 2 - 4 } & 2017 & 102,7 & 62,9 \\
\cline { 2 - 4 } & 2018 & 98,7 & 60,9 \\
\cline { 2 - 4 } & 2019 & 185,5 & 66,8 \\
\cline { 2 - 4 } & 2020 & 124,5 & 35,0 \\
\hline Предприятия других отраслей & 2016 & 206,7 & 46,9 \\
\cline { 2 - 4 } & 2017 & 31,8 & 35,3 \\
\cline { 2 - 4 } & 2018 & 56,1 & 80,6 \\
\cline { 2 - 4 } & 2019 & 51,5 & 100,0 \\
\cline { 2 - 4 } & 2020 & 383,7 & 55,6 \\
\hline
\end{tabular}

Источник. Авторская разработка на основе аналитических отчетов Банка развития Республики Беларусь за 2016-2020 гг. 
проекты, а также проекты транспорта и связи.

В 2016-2020 гг. объемы и темпы выдачи инвестиционных кредитов предприятиям обрабатывающей промышленности (за исключением пищевой отрасли) ускоренно росли и достигли 20\% в портфеле Банка развития (табл. 8).

Банк, как национальный институт развития, отбирает проекты к финансированию, значимые для развития приоритетных секторов экономики страны и обладающие высоким социально-экономическим и мультипликативным эффектом. С целью качественного и количественного прогноза влияния инвестиций Банка развития на экономику страны по каждому проекту, принятому к финансированию в сфере обрабатывающей промышленности, рассчитывается Индекс эффекта от реализации проекта (ИЭРП), который характеризует макроэкономический, технологический и социальный эффекты от реализации проекта. Индекс определяет выраженную в баллах величину эффекта от профинансированных Банком инвестиционных проектов для социально-экономического развития страны. Максимальное количество баллов, которое можно набрать, равно 100.

На рис. 2 представлены данные о средневзвешенных значениях индекса эффекта от реализации проекта, рассчитанных за анализируемый период по отобранным Бан- ком развития инвестиционным проектам. Как видим, Банком развития в среднем отбираются проекты с достаточно высокими значениями ИЭРП: на протяжении анализируемого периода значения показателя не опускались ниже 50. Однако, несмотря на его рост с 2016 по 2018 г., в дальнейшем значения индекса постоянно снижаются, достигнув в 2020 г. своего минимального значения.

Проведенный анализ системы государственной финансовой поддержки инвестиционных проектов в промышленности Республики Беларусь показал, что их реализация не всегда соответствовала по тем или иным причинам ожидаемым результатам. Поэтому сложившиеся в стране формы и критерии господдержки нуждаются в определенной трансформации и повышении ее эффективности.

Если обратиться к зарубежному опыту оказания господдержки, то в общих чертах он сводится к следующему.

Целесообразность участия государства в реализации инвестиционных проектов постоянно является предметом научных дискуссий. При этом точки зрения отдельных экономистов по данному вопросу бывают часто противоположными (А. Смит, Дж. М. Кейнс, К. Эрроу, Ж. Дебре, Дж. Стиглиц и др.). В рамках данной дискуссии сформировались два основных подхода: неолиберальный (вмешательство государ-

Показатели инвестиционного кредитования Банком развития, в том числе предприятий обрабатывающей промышленности, 2014-2020 гг.

\begin{tabular}{|l|c|c|c|c|c|c|c|}
\hline \multicolumn{1}{|c|}{ Показатель } & 2014 & 2015 & 2016 & 2017 & 2018 & 2019 & 2020 \\
\hline Выданные инвестиционные кредиты, млн руб. & 507,2 & 888,4 & 916,4 & 965,5 & 1491,4 & 1449,0 & 2072,5 \\
\hline $\begin{array}{l}\text { Темп роста выданных инвестиционных креди- } \\
\text { тов по сравнению с предыдущим годом, \% }\end{array}$ & - & 175,2 & 103,2 & 105,4 & 154,5 & 97,2 & 143,0 \\
\hline $\begin{array}{l}\text { Инвестиционное финансирование } \\
\text { обрабатывающей промышленности } \\
\text { (за исключением пищевой), млн руб. }\end{array}$ & - & - & 105,0 & 99,4 & 170,8 & 224,6 & 417,5 \\
\hline $\begin{array}{l}\text { Темп роста выданных инвестицинных } \\
\text { кредитов организациям обрабатывающей } \\
\text { промышленности (за исключением пищевой) } \\
\text { по сравнению с предыдущим годом, \% }\end{array}$ & - & - & - & 94,7 & 171,8 & 131,5 & 185,9 \\
\hline $\begin{array}{l}\text { Доля инвестиционных кредитов, выданных } \\
\text { организациям обрабатывающей } \\
\text { промышленности (за исключением пищевой) } \\
\text { в общей сумме инвестицинного } \\
\text { кредитования Банком развития, \% }\end{array}$ & - & - & 11,5 & 10,3 & 11,5 & 15,5 & 20,1 \\
\hline
\end{tabular}

Источник. Авторская разработка на основе аналитических отчетов Банка развития Республики Беларусь за 2016-2020 гг. 


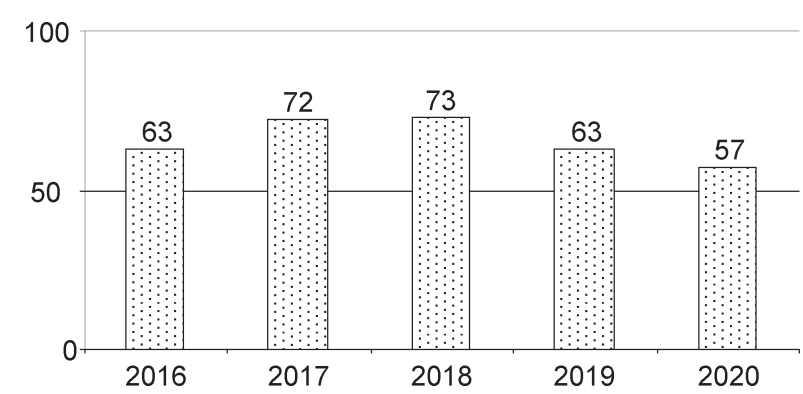

Рис. 2. Значения индекса эффекта от реализации проектов, отобранных и профинансированных

Банком развития, 2016-2020 гг.

Источник. Авторская разработка на основе аналитических отчетов Банка развития Республики Беларусь, 2016-2020 гг.

ства в рамках реализации структурной и промышленной политики приводит к искажениям работы рыночного механизма, торможению экономического развития и снижению общественного благосостояния) и структуралистский (меры государственной промышленной политики могут оказаться необходимыми для обеспечения позитивной динамики экономического развития) ${ }^{30}$.

Нередко государственное участие оправдывается сложившимися особенностями экономики (асимметричность информации, несовершенство финансовых рынков). Американский экономист М.Ю. Портер, обосновывая возможность предоставления различных форм государственной поддержки, отмечал: «...субсидируемый капитал, субсидируемые исследования, субсидируемое сырье, субсидируемый экспорт и прямые дотации используются почти в каждой стране» (Портер, 1993).

Для ограничения степени участия государства в реализации инвестиционных проектов Всемирным банком были определены условия, при которых оно будет целесообразно:

1) для тех проектов, которые несут значительные риски реализации для частных инвесторов;

2) если стоимость капитала для государства как партиципанта проекта ниже, чем для частного сектора;

${ }^{30}$ Мельников Р.М. 2016. Оценка эффективности общественно значимых инвестиционных проектов методом анализа издержек и выгод: учебное пособие. Москва: Проспект.
3) для крупных по размеру и стоимости проектов (мегапроектов), затраты на реализацию которых требуют аккумулирования значительных сумм денежных средств (Belli, 2001).

Приведенные выше условия носят опциональный характер, и не все государства ими руководствуются при обосновании решения участия в проекте.

Применяемые формы государственной финансовой поддержки зависят от проводимой инвестиционной политики, исторического этапа развития страны, степени развития национальной финансовой системы и финансовых рынков, а также зрелости и формы собственности организаций, реализующих инвестиционный проект.

Лидером по количеству применяемых форм государственной финансовой поддержки на реализацию инвестиционных проектов является Российская Федерация, среди стран ЕС - Германия, причем в соответствии с программой регионального развития формы используются только для организаций, расположенных на территории бывшей ГДР.

В свою очередь, данные по формам государственного финансового участия в реализации инвестиционных проектов в странах ЕС не являются исчерпывающими и статичными. Это связано, прежде всего, с тем, что финансовое участие страны члена ЕС в реализации коммерчески эффективного инвестиционного проекта официально возможно только в рамках программы региональной помощи. В то же время правительствами многих стран используются иные программы государственной поддержки, имеющие косвенное отношение к инвестиционным проектам (например, поддержка малого и среднего бизнеса или занятости населения), что не позволяет полностью учесть применяемые формы государственной финансовой поддержки. Тем не менее прямое финансовое участие в реализации инвестиционного проекта странами - членами ЕС представлено в основном системой грантов, а косвенное - налоговыми вычетами, льготами и кредитами. Достаточно редко странами ЕС используются государственные гарантии по кредитам, выданным на реализацию инвестици- 
онного проекта ${ }^{31}$. Последняя форма направлена на поддержку малого и среднего бизнеса в целях облегчения привлечения заемного капитала. В целом нельзя совершенно однозначно определить преобладание в использовании прямых форм над косвенными.

В постсоветский странах, таких как Украина, Казахстан, система грантов получила меньшее распространение. В последние годы все активнее к ней прибегают в Российской Федерации, особенно для субъектов МСБ и на региональном уровне ${ }^{32}$.

В Республике Беларусь гранты предоставляются при реализации инновационных проектов. В последние годы Банком развития предпринят ряд мер по постепенной рационализации сложившейся в республике системы государственной финансовой поддержки реализации инвестиционных проектов с усилением рыночных конкурентных подходов и с учетом зарубежного опыта. Прежде всего внесены определенные изменения в важнейший для деятельности Банка развития Указ Президента Республики Беларусь № 261, что способствовало формированию правовых условий для поэтапного перехода от директивного к преимущественно рыночному кредитованию. Данные подходы начали применяться с 2020 г., когда банком были самостоятельно отобраны и профинансированы первые проекты. При этом отбор проектов проводился посредством преимущественного использования конкурсных процедур, что позволило уйти от преобладающей в Беларуси индивидуальной господдержки при реализации инвестиционных проектов. Для повышения качества отбираемых проектов через их эк-

${ }^{31}$ Ex-post evaluation of the Regional Aid Guidelines 20072013. Final report. URL: https://op.europa.eu/en/publicationdetail/-/publication/12d6f796-11b1-4a7b-9e1b-c8cdf58cff32/ language-en: «Transparency system» for regional aid for large investment projects. URL:http://ec.europa.eu/competition/ consultations/2013_regional_aid_guidelines/study_rag_ evaluation_en.pdf; Аналитическая информация о мерах государственной поддержки легкой промышленности в государствах - членах Европейского союза и государствах ЮгоВосточной Азии. URL: http://www.eurasiancommission.org/ru/ act/prom_i_agroprom/dep_prom/SiteAssets

32 Федеральный закон РФ от 25.02.1999 г. № 39-ФЗ «Об инвестиционной деятельности в Российской Федерации, осуществляемой в форме капитальных вложений» (в ред. Федер. закона от 26.07.2017 г. № 205-Ф3); Постановление Правительства Российской Федерации от 18.01.2017 г. № 30 «Об утверждении Правил предоставления субсидий из феде- спертизу в Банке развития создано соответствующее проектное бюро.

Особо следует отметить предпринятые в Банке развития меры по трансформации льготного кредитования в рыночное с одновременным освоением и нормативной регламентацией так называемых бюджетных трансфертов, которые частично компенсируют кредитополучателям понесенные инвестиционные расходы. При этом предоставляемые трансферты носят стимулирующий характер и направлены на ускорение завершения инвестиционного проекта с выходом на полную производственную мощность.

Косвенно реализации инвестиционных проектов способствуют лизинг (формирует спрос и способствует приобретению оборудования и транспортных средств) и экспортное кредитование (например, под реализацию белорусской машиностроительной продукции). По инициативе Банка развития внесены изменения в указ № 146 в части условий осуществления лизинговых операций. Прежде всего они касаются расширения количества лизинговых компаний и замены прямого льготирования лизинговой ставки на частичное субсидирование лизинговых платежей. В рамках экспортного кредитования банк поддержал отдельные белорусские машиностроительные предприятия при экспорте их продукции.

Для привлечения дополнительных ресурсов под инвестиционное кредитование Банком развития весной 2019 г. успешно проведено размещение еврооблигаций на сумму 500 млн долл. США.

Особо следует остановиться на развитии специфических для Беларуси и акту-

рального бюджета организациям легкой и текстильной промышленности на возмещение части затрат на уплату процентов по кредитам, полученным в российских кредитных организациях в 2013-2018 годах, на реализацию новых инвестиционных проектов по техническому перевооружению и признании утратившими силу некоторых актов Правительства Российской Федерации» (в ред. постановления Правительства Российской Федерации от 27.12.2017 г. № 1654); Закон Республики Казахстан от 25.10.2015 г. № 375-V ЗРК «Предпринимательский кодекс Республики Казахстан» (в ред. Закона Республики Казахстан от 04.07.2018 г. № 174-VI); Формы государственной поддержки промышленности. Государственная программа «Развитие промышленности и повышение ее конкурентоспособности». URL: http://minpromtorg.gov.ru/common/ upload/files/docs/GP_razvitie_promyshlenosti_povysh_ konkurentosposobnosti[1].pdf 
альных в условиях сложившейся экономической ситуации формах господдержки, которые в последнее время пытается осваивать Банк развития. В первую очередь, следует отметить в этом плане опыт Банка по санированию финансового состояния и выводу на относительно устойчивую работу 9 модернизированных предприятий деревообработки, которые он получил, по сути, в антикризисное управление в 2016 г. На тот момент данные предприятия находились в сложном финансовом положении, загрузка отдельных производственных мощностей составляла порядка 15-20\%, имели место длительные просрочки по обязательствам.

Усилиями Банка развития были рационализированы бизнес-процессы, восстановлены оборотные средства, стабилизировано финансовое состояние, и уже в 2018 г. большинство цехов данных предприятий вышло на максимальную загрузку (за исключением сбытовых ограничений) и рентабельную работу. Стали даже начислять амортизацию и проводить точечную модернизацию и автоматизацию отдельных производственных процессов. В целях удержания цен и недопущения неоправданной конкуренции были организованы продажи через «Белорусскую лесную компанию». В свою очередь, централизация закупок позволила получить эффект масштаба и сократить нарушения при осуществлении закупочной деятельности. В дальнейшем данные предприятия деревообработки снова перешли в подчинение концерну «Беллесбумпром».

Однако в 2019 г. резко упали мировые цены на продукцию деревообработки (особенно на фанеру и ДСП), что привело к обнулению рентабельности и вновь осложнило расчеты по кредитам и займам, рассроченным налоговым платежам, исполненным правительственным гарантиям. В свою очередь, в 2021 г. внешнеторговая конъюнктура на продукцию деревообрабатывающей отрасли существенно улучшилась.

Одновременно был запущен пилотный проект с привлечением ЕБРР (в настоящее время сотрудничество с госсектором, к сожалению, приостановлено) по предприватизационной подготовке ОАО «Витебскд- рев». Данная процедура в случае успешности ее осуществления могла привести к привлечению инвестора на коммерческое предприятие или хотя бы выявить в процессе консультирования сильные и наиболее слабые места в структуре и организации производства, возможности рационализации финансовых потоков.

На наш взгляд, активизация участия банков в доверительном трастовом управлении проблемными государственными коммерческими предприятиями, учитывая положительный опыт в этом плане Банка развития, представляется в сложившейся экономической ситуации одним из перспективных подходов, способствующим их санации и повышению привлекательности для частных инвесторов, особенно с учетом следующих моментов.

Беларусь придерживалась осторожных подходов в области приватизации промышленных предприятий и не воспользовалась данным инструментом по привлечению инвесторов, когда для этого были более благоприятные условия и возможности (особенно в 2000-2007 гг. и первой половине 2008 г.). В дальнейшем попытки приватизации отдельных белорусских предприятий традиционными способами не дали результатов.

Выставленные на приватизацию в 2011 г. НАИП совместно с МБРР 8 пилотных проектов, а также объявление в 2016 г. 2 международных конкурсов по привлечению стратегических инвесторов на ОАО «Минский маргариновый завод» и ОАО «Барановичский комбинат железобетонных конструкций» так и не нашли покупателей. Кроме того, оформление данных сделок требует двух и более лет. Эксперты компании «Юнитер» утверждают, что инвестор ориентируется на окупаемость инвестиций в Беларуси в течение 5-6 лет. К тому же республика проигрывает в части стоимости факторов производства Российской Федерации и Казахстану. Как известно, в этих странах дешевле энергоресурсы и сырье, ниже налоги в обрабатывающих отраслях, отчисления на соцстрах, больше емкость внутреннего рынка, применяются более современные рыночные подходы в коммерческих компаниях с частным иностранным и отечественным капиталом. Нельзя не учитывать и то, что за 
последние годы в Российской Федерации активно проводилась промышленная политика восстановления и создания ряда предприятий и производств (преимущественно с более эффективным частным капиталом), которые успешно конкурируют с аналогичными белорусскими товаропроизводителями (Матяс, 2017).

Из других перспективных направлений повышения результативности господдержки с одновременным замещением проблемного госсектора более эффективным частным в условиях сложности быстрого привлечения внешнего инвестора представляется присоединение к успешным частным предприятиям или созданным с их участием холдингам отдельных государственных активов. В качестве примера в этом отношении можно отметить ООО «Управляющая компания холдинга «Белорусская кожевенно-обувная компания «Марко».

В соответствии с постановлением Совмина № 175 от 27.03.2021 г. данной частной компании оказана господдержка из республиканского бюджета в виде возмещения части процентов по кредитам, которые привлечены не только под реализацию инвестиционного проекта по расширению производства обуви, но и реконструкцию присоединенного и проблемного мехового комбината в рамках созданного холдинга. Господдержка будет способствовать укрупнению активов с учетом кластерного подхода и сокращению неэффективного госсектора.

Таким образом, для получения государственной финансовой поддержки на реализацию инвестиционного проекта коммерческое предприятие должно соответствовать определенным требованиям, устанавливаемым законодательно. Одним из условий ее предоставления является соответствие критериям эффективности, определяемым индивидуально в зависимости от формы финансового участия государства.

Несоблюдение условий эффективности не всегда приводит к прекращению финансового участия государства в реализации инвестиционного проекта.
Используются как общие формы государственной финансовой поддержки, предоставляемые на конкурсной основе или при соблюдении определенных требований и критериев эффективности, так и индивидуальные, для отдельных предприятий, которые могут включать в себя формы, не предусмотренные законодательно для других организаций.

Сопоставление прямых и косвенных форм государственной финансовой поддержки, проведенное по предприятиям, финансирование которых осуществлялось за счет внешних государственных займов и внешних займов, привлеченных под гарантии Правительства Республики Беларусь, указывает на преобладание доли первых.

При оказании государственной финансовой поддержки в форме возмещения части процентов по кредитам на условиях конкурсного размещения высока доля предприятий, которым данная форма предоставлялась не единожды. При этом критерий эффективности в виде показателя рентабельности продаж соблюдался практически за весь анализируемый период.

Объемы исполненных обязательств по гарантиям, предоставленным по кредитам, которые выданы на реализацию инвестиционных проектов, увеличиваются.

Возникала потребность в дополнительных бюджетных вливаниях на завершение реализации инвестиционных проектов с финансовым участием государства по отдельным предприятиям.

В целом объемы господдержки существенно увеличиваются как в годы реализации масштабных программ сплошной модернизации отдельных отраслей (в частности, в 2012-2014 гг.), так и при дополнительной поддержке предприятий по причине затягивания сроков (до 3 лет и более) реализации данных проектов и чрезмерно оптимистичных оценок стоимости и эффективности реализуемых инвестпроектов. При этом данная ситуация усугубляется из-за их недостаточной маркетинговой проработки, связанной как с ухудшением внешнеторговой конъюнктуры, так и в целом макроэкономической ситуации в стране.

В качестве основных макроэкономических факторов, оказавших негативное влия- 
ние на эффективность реализации инвестиционных проектов с государственной финансовой поддержкой, следует отметить: периодическую и существенную девальвацию белорусского рубля; высокую инфляцию в Беларуси на протяжении длительного времени и, как следствие, высокие процентные ставки по кредитам; девальвацию отдельных иностранных валют (в частности, российского рубля в 2014 г.) и периодическое ухудшение конъюнктуры на традиционных рынков сбыта высокоэластичной продукции модернизированных предприятий.

Во избежание в будущем финансирования потенциально неэффективных инвестиционных проектов, а также несения дополнительных расходов из бюджетов и внебюджетных фондов для исполнения государством взятых на себя обязательств одним из направлений улучшения системы оказания государственной финансовой поддержки, на наш взгляд, является учет интересов государства на стадии планирования, выраженный в четко сформулированных критериях бюджетной эффективности.

Правительством и Министерством финансов Республики Беларусь в отдельные годы предпринимаются меры по уменьшению выделяемых из бюджетов и внебюджетных фондов сумм государственной финансовой поддержки неэффективным коммерческим предприятиям и неперспективным инвестиционным проектам и снижению фискальных рисков на государственный бюджет, в том числе за счет сокращения количества форм государственной финансовой помощи, введения дополнительных критериев и конкурсного подхода. Однако у Правительства Республики Беларусь по отдельным проблемным предприятиям существуют обязательства до 2029 г. и на более длительные сроки (предприятия деревообработки, цементной отрасли), что окажет влияние на состояние государственных финансов на ближайшие и последующие годы.

В Беларуси, учитывая доминирование в экономике государственного сектора и крупных валообразующих предприятий, пока придерживаются более осторожных подходов, направленных на постепенное изменение управления госсектором и сложившейся системы его господдержки. Это касается прежде всего разделения функций собственника и оперативного управления, ликвидации избыточных функций министерств, демонополизации, реализации промышленной политики в рамках создания и управления крупными интегрированными структурами, перехода от индивидуальной господдержки к отраслевым преференциям и субсидиям, обеспечения равного доступа субъектов хозяйствования к господдержке независимо от форм собственности и увязка данной господдержки с конечными результатами. При этом учитывается и существующая в настоящее время проблема привлечения эффективных инвесторов.

В последние годы Банком развития предпринят ряд мер по постепенной рационализации сложившейся в Беларуси системы государственной финансовой поддержки реализации инвестиционных проектов с усилением рыночных конкурентных подходов и с учетом зарубежного опыта.

Активизация участия банков в доверительном трастовом управлении проблемными предприятиями с большой долей государства в их капитале (по примеру ОАО «Банк развития Республики Беларусь», взявшему в антикризисное управление 9 проблемных предприятий деревообработки после их модернизации), но с дальнейшей их приватизацией частными стратегическими инвесторами представляется в сложившейся экономической ситуации одним из перспективных подходов.

Из других перспективных направлений повышения результативности господдержки с одновременным замещением проблемного госсектора более эффективным частным в условиях сложности быстрого привлечения внешнего инвестора представляется присоединение к успешным частным предприятиям или созданным с их участием холдингам отдельных государственных активов.

\section{СПИСОК ЛИТЕРАТУРЫ (REFERENCES)}

Голикова А.С. 2017. Механизмы государственного участия в реализации инвестиционных проектов. Белорусский экономический журнал. № 1. C. 49-65. [Golikova A.S. 2017. Mechanisms of government involvement in the implementation of 
investment projects. Belorusskiy ekonomicheskiy zhurnal. No 1. PP. 49-65. (In Russ.)]

Гусаков В.Г. (Ред.). 2015. Социально-экономическая модель: становление и развитие: теория, методология, практика. Кн. 2. Минск: Беларуская навука. [Gusakov V.G. (Ed.) 2015. Socioeconomic model: Formation and development: Theory, methodology, practice. Minsk: Belaruskaya navuka. (In Russ.)]

Матвеев Д.Г. 2014. Особенности и приоритеты государственной поддержки экономики Беларуси на современном этапе. Белорусский экономический журнал. № 3. C. 29-44. [Matveev D.G. 2014. Specifics and priorities of the current state support of Belarus's economy. Belorusskiy ekonomicheskiy zhurnal. No 3. PP. 29-44. (In Russ.)]

Портер М.Е. 1993. Международная конкуренщия: конкурентные преимущества стран. Москва: Международные отношения. [Porter M.E. 1993. International competition: Competitive advantages of countries. Moscow: Mezhdunarodnye otnosheniya. (In Russ.)]

Преснякова Е.В., Матейчук Т.С., Зайцева Е.В. 2017. Механизм стимулирования взаимных инвестиций Республики Беларусь и госу- дарств - членов Евразийского экономического союза. Минск: Институт экономики НАН Беларуси. [Presnyakova E.V., Mateichuk T.S., Zaitseva E.V. 2017. A mechanism for stimulating mutual investments of the Republic of Belarus and the member states of the Eurasian Economic Union. Minsk: Institut ekonomiki NAN Belarusi. (In Russ.)]

Рудый К.В. 2016. Беларусь - Китай: каналы инвестиционного сотрудничества. Белорусский экономический журнал. № 2. C. 15-30. [Rudy K.V. 2016. Belarus - China: Channels of investment cooperation. Belorusskiy ekonomicheskiy zhumal. No 2. PP. 15-30. (In Russ.)]

Матяс А.А. 2017. Макроэкономическая и структурная политика в Республике Беларусь: ретроспективный анализ, проблемы и направления развития. Белорусский әкономический журнал. № 3. C. 7-23. [Matyas A.A. 2017. Macroeconomic and structural policies in the Republic of Belarus: A retrospective analysis, problems, and directions of development. Belorusskiy ekonomicheskiy zhurnal. No 3. PP. 7-23. (In Russ.)]

Belli P. (Ed.). 2001. Economic analysis of investment operations: Analytical tools and practical applications. Washington, DC: World Bank.

\title{
RETROSPECTIVE ANALYSIS OF THE FORMS OF STATE FINANCIAL SUPPORT FOR INVESTMENT PROJECTS IN THE INDUSTRY OF THE REPUBLIC OF BELARUS
}

\author{
Anna Golikova ${ }^{1}$, Aliaksandar Matyas ${ }^{1}$ \\ Author affiliation: ${ }^{1}$ Polessky State University (Pinsk, Belarus). \\ Corresponding author: Alexander Matyas (alexandermatyas@yandex.ru).
}

ABSTRACT. The article presents a retrospective analysis of the forms and criteria of state financial support for the implementation of investment projects in the industry of the Republic of Belarus.It is based on the use of the relevant regulatory legal acts, actual data of government bodies, the banking sector and individual modernized commercial organizations. The article also identifies the features, individual trends, existing problems, possible directions and measures for the gradual transformation and rationalization of this support.

KEYWORDS: The Republic of Belarus, forms of state financial support, investment projects, industry.

JEL-code: H54, H81.

DOI: $10.46782 / 1818-4510-2021-4-89-112$

Received 6.12.2021 